\title{
Comparison between bipolar vessel sealer (LigaSure vessel sealer) and harmonic scalpel in total laparoscopic hysterectomy
}

\author{
Vandana Bansal $^{1,2}$, Arpit Bansal ${ }^{3}$, Ashwani Kumar Bansal ${ }^{3}$, Ajay Kumar ${ }^{4}$ \\ ${ }^{1}$ Department of Obstetrics \& Gynecology, Jeevan Jyoti Hospital, Allahabad, U.P., India \\ ${ }^{2}$ Department of Obstetrics \& Gynecology, Guru Gobind Singh Memorial Vanadana Women's Hospital, Allahabad, \\ U.P., India \\ ${ }^{3}$ Department of Surgery, Jeevan Jyoti Hospital, Allahabad, U.P., India \\ ${ }^{4}$ Jeevan Jyoti Institute of Medical Sciences, Allahabad, U.P., India
}

Received: 25 September 2014

Accepted: 22 October 2014

\section{*Correspondence:}

Dr. Vandana Bansal,

E-mail: bansal.drvandana@gmail.com,drvandanaresearch@gmail.com

Copyright: (C) the author(s), publisher and licensee Medip Academy. This is an open-access article distributed under the terms of the Creative Commons Attribution Non-Commercial License, which permits unrestricted non-commercial use, distribution, and reproduction in any medium, provided the original work is properly cited.

\begin{abstract}
Background: The aim of the present study was to compare the use of bipolar Vessel Sealer with Harmonic Scalpel (HS) during total laparoscopic hysterectomy with respect to estimated blood loss and related postoperative complications.

Methods: A retrospective study was conducted in the Jeevan Jyoti hospital and Guru Gobind Singh Memorial Vanadana Women's hospital, Allahabad, U.P., India. Two forty two patients were enrolled who underwent total laparoscopic hysterectomy and were randomized into two homogenous groups: bipolar vessel sealer and harmonic scalpel.

Results: Estimated blood loss was significantly less in bipolar vessel sealer when compared with harmonic scalpel. No significant difference was observed in postoperative complications.

Conclusions: The bipolar vessel sealer is a reliable and safe tool for reducing intraoperative blood loss in patients undergoing total laparoscopic hysterectomy. More randomized studies need to be done to confirm the advantages of this technique.
\end{abstract}

Keywords: Bipolar vessel sealer, Laparoscopy, Harmonic scalpel, Hysterectomy

\section{INTRODUCTION}

A conventional hysterectomy involves removing the uterus through an abdominal incision or through the vagina. The cervix may be removed along with the uterus (total hysterectomy) or it can be left in situ (subtotal or supracervical hysterectomy). A minimally invasive and tissue respectful technique with minimal tissue damage is the aim of all surgical techniques. Colpotomy in total laparoscopic hysterectomy is generally done using an energy source; the most common ones being monopolar energy or harmonic.

Hysterectomy is the most commonly performed major gynecologic procedure around the world. Benign diseases are responsible for more than $70 \%$ of the indications for hysterectomy and include menstrual disorders, fibroids, pelvic pain and uterine prolapsed. ${ }^{1}$

Total Laparoscopic Hysterectomy (TLH) was first proposed in the early 1990's by Reich \& Liu. The aim was for a clear, precise approach with reduced blood loss and hospital stay compared to Laparoscopically-Assisted Vaginal Hysterectomy (LAVH).

In TLH, all the procedure is performed by laparoscopic techniques. A hemostatic cutting device such as monopolar or bipolar diathermy scissors, stapling gun, or harmonic scalpel is used to detach the uterus completely from surrounding and supporting structures including 
ligaments and blood vessels. The uterus is then removed through the vagina, or may be cut into small pieces, and removed through one of the abdominal ports.

The advantages of the laparoscopic approach compared to open surgery include less intraoperative bleeding, shorter hospital stay, faster recovery and lower rates of wound and/or abdominal wall infections, at the expense of a longer surgery. ${ }^{2}$

The incidence of vaginal scar dehiscence is found to be higher in total laparoscopic hysterectomy than either abdominal or vaginal hysterectomy. ${ }^{3}$

All coagulation devices have a distinct thermal spread which is dependent on the type of mode, the application time and the power setting. Hefermehl et al. found that monopolar mode causes thermal spread of $3.5 \mathrm{~mm}$ when applied for 1 second and after 2 seconds the spread was more than $20 \mathrm{~mm}$. For bipolar mode it was $2.2 \mathrm{~mm}$ for 1 second and $3.6 \mathrm{~mm}$ at 2 seconds, for PK and LigaSure it was $3.9 \mathrm{~mm}$ and $2.8 \mathrm{~mm}$ respectively. For ultrasound the thermal spread was $2.9 \mathrm{~mm}^{4}$

The harmonic scalpel is a high frequency ultrasonic transducer. The active titanium blade vibrates at 55000 cycles per second. The resulting mechanical energy causes a breakdown of protein in tissues which creates a coagulum. Vessel and tissue sealing is dependent on the power setting as well as the pressure exerted, the formation of the coagulum and tissue tension. The harmonic scalpel performs at lower temperatures (50-1 00 degrees Celsius) while other devices work at higher temperatures (150 to 400 degrees Celsius), causing desiccation and charring.

In this study we compare Total Laparoscopic Hysterectomy (TLH) with the harmonic scalpel with bipolar diathermy (LigaSure vessel sealing) TLH.

\section{METHODS}

This study was a randomized clinical trial conducted in the obstetrics and gynecology department of Jeevan Jyoti Hospital, Allahabad, U.P. India, from March 2012 till April 2014.

Fifty subjects for TLH were randomly divided into two groups. Group (I) was assigned for TLH using the Harmonic scalpel and group (II) was assigned for bipolar diathermy. Each one of the two techniques used in the study was written in a card and was put in an envelope; the fifty one envelops were all identical. Serially numbered sealed envelopes were held securely by trained nurse. The circulating nurse was asked to pull any card just before preparation for surgery. The patients were aware of the treatment methods and signed an informed consent, and they had equal chances of entering any of the trial groups.
An informed consent was taken from all patients; all women were subjected to the following examination: clinical history, physical examination, abdominal examination, vaginal examination, cervical Pap smear and ultrasound examination.

\section{Inclusion and exclusion criteria}

All the patients who gave the consent and the gynecologist give the opinion for the hysterectomy, with negative Pap smear were included in the study. Those patients having suspected or confirmed malignancy in any part of the genital system, uterine size greater than the 12 weak pregnancy, contraindication of the laparoscopic surgery and if not given the consent were excluded from the study.

All operations were done by the same surgeon and surgical team followed by slandered procedure. Postoperative care included vital sign like temperature, blood pressure, pulse and respiratory rate on every 6 hours. The blood loss was estimated by drop of $\mathrm{Hb} \%$ from preoperative condition.

Data about the patients' characteristics, operation time, estimated blood loss, related complications and length of hospital stay were registered and compared.

\section{Statistical analysis}

Data were collected and entered into the SPSS version 12 for Windows. Qualitative variables were expressed as number and percentage while quantitative variables were expressed as mean and standard deviation and the significance ( $\mathrm{P}$ value) was also calculated.

\section{RESULTS}

This study comprised 51 patients divided into 2 groups. Group (I) underwent TLH operation using the Harmonic Scalpel (HS). Group (II) patients had the TLH operation using the electro-thermal bipolar vessel sealer technique. The demographic data are present in Table 1.

Table 1: Character of the study group.

\begin{tabular}{|llll|} 
& $\begin{array}{l}\text { Group I } \\
(\mathrm{N}=121)\end{array}$ & $\begin{array}{l}\text { Group II } \\
(\mathrm{N}=121)\end{array}$ & P value \\
\hline Age (year) & $44.17 \pm 5.34$ & $45.67 \pm 4.15$ & 0.067 \\
\hline Parity & 9 & 13 & 0.082 \\
\hline $\begin{array}{l}\text { Body mass index } \\
\text { (BMI) }\end{array}$ & $29.47 \pm 2.17$ & $32.28 \pm 3.26$ & 0.063 \\
\hline Preoperative $\mathrm{Hb}$ & $12.41 \pm 1.75$ & $11.85 \pm 1.25$ & 0.079 \\
\hline $\begin{array}{l}\text { Preoperative } \\
\text { hematocrit }\end{array}$ & $36.20 \pm 3.46$ & $35.75 \pm 2.85$ & 0.104 \\
\hline
\end{tabular}

During the procedure it was observed that bipolar vessel sealer method of TLH consume less time $(76.16 \pm 12.14)$ than the HS (115.35 \pm 18.25). Blood loss during 
operation was significantly lower in group (II) patients compared to group (I). There was significant greater drop in hemoglobin and hematocrit in the latter compared to the former group. The mean hemoglobin drop in group (I) patients was $(3.12 \pm 0.85)$ and in group (II) was $(0.54 \pm$ $0.29)$. The mean hematocrit drop was $(3.62 \pm 0.72)$ in group (I) and $(0.85 \pm 0.37)$ in group (II). The mean hospital stay time for group (I) patients was $1.13 \pm 0.12$ days and in group (II) it was $1.55 \pm 0.27$ days which was not statistically significant $(\mathrm{P}>0.005)$ (Table.2).

Table 2: Operative and post-operative details.

\begin{tabular}{|c|c|c|c|c|}
\hline Factors & & No. & Mean \pm SD & P value \\
\hline \multirow{2}{*}{$\begin{array}{l}\text { Operation } \\
\text { time }\end{array}$} & Group I & 121 & $115.35 \pm 18.25$ & \multirow{2}{*}{$<0.005$} \\
\hline & Group II & 121 & $76.16 \pm 12.14$ & \\
\hline \multirow{2}{*}{$\begin{array}{l}\text { Blood loss } \\
(\mathrm{ml})\end{array}$} & Group I & 121 & $140.84 \pm 48.92$ & \multirow{2}{*}{$<0.005$} \\
\hline & Group II & 121 & $88.74 \pm 24.46$ & \\
\hline \multirow{2}{*}{$\begin{array}{l}\text { Haemoglobin } \\
\text { drop\% }\end{array}$} & Group I & 121 & $3.12 \pm 0.85$ & \multirow{2}{*}{$<0.005$} \\
\hline & Group II & 121 & $0.54 \pm 0.29$ & \\
\hline \multirow{2}{*}{$\begin{array}{l}\text { Haematocrit } \\
\text { drop } \%\end{array}$} & Group I & 121 & $3.62 \pm 0.72$ & \multirow{2}{*}{$<0.005$} \\
\hline & Group II & 121 & $0.85 \pm 0.37$ & \\
\hline \multirow{2}{*}{ Hospital stay } & Group I & 121 & $1.13 \pm 0.12$ & \multirow{2}{*}{$>0.005$} \\
\hline & Group II & 121 & $1.55 \pm 0.27$ & \\
\hline
\end{tabular}

\section{Complication}

The rate of complication was higher among group (I) patients $7(28 \%)$ as compared to group (II) patients 3 $(12 \%)$; however the difference was not statistically significant. Complications were noted as intra-operative bleeding from larger vascular stumps or uterine vessels.

\section{DISCUSSION}

Over the last ten years, gynecologists have been obtaining the necessary skills to perform Laparoscopically Assisted Vaginal Hysterectomies (LAVH) or Total Laparoscopic Hysterectomies (TLH) in order to convert an abdominal procedure into a laparoscopic/vaginal procedure. ${ }^{5}$

It provides a high degree of safety by heating tissue to form a protein coagulum, which gives excellent hemostasis at a significantly lower temperature than standard electrosurgery, thus decreasing the risk of thermal injury to surrounding tissue than the diathermy method of hysterectomy.

Bipolar diathermy was found to be less time-consuming and less bleeding when compared to harmonic scalpel. Mean procedure time was $(115.35 \pm 18.25 \mathrm{~min})$ in harmonic scalpel and was (73.16 $\pm 12.14 \mathrm{~min})$ in diathermy which was statistically significant. The estimated blood loss were significantly less in the bipolar diathermy compared to the harmonic scalpel (88.74 \pm 24.46 vs. $140.84 \pm 48.92 \mathrm{~mL}$; $\mathrm{P}<0.005$, respectively). The changes in hemoglobin and hematocrit values were found to be more significant in the harmonic scalpel group. Our study demonstrated similar results when compared to Campagnacci et al., ${ }^{6}$ Demirturk et al. work, ${ }^{7}$ and Ashraf TA et al. ${ }^{8}$ Akira Tsunoda also stated that bipolar diathermy is quick and bloodless and, although as painful as compared with the ultrasonic scalpel, is associated with a reduced analgesic requirement immediately after operation. ${ }^{9}$

Our work revealed that blood loss during operation was significantly lower in bipolar vessel sealer group compared to HS group demonstrated by significant greater drop in hemoglobin and hematocrit in the latter compared to the former group. This could be attributed to the limited ability of HS technique to deal with larger vascular stumps such as the infundibulo-pelvic and large uterine stumps.

Bleeding stumps were manifested intraoperatively in 26 out of $121(21.49 \%)$ patients in the HS group, compared to 9 out of $121(7.44 \%)$ in the biopolar Vessel Sealer group the difference was not statistically significant similar result was observed by Demirturk $\mathrm{F}$ et al. ${ }^{7}$ and Ashraf TA et al. ${ }^{8}$

\section{CONCLUSION}

The bipolar vessel sealer technique seems to be less timeconsuming and less blood loss during operation when compared with harmonic shears. Further studies with larger number of patients are required for stronger evaluation of the technique.

\section{Funding: No funding sources Conflict of interest: None declared \\ Ethical approval: The study was approved by the institutional ethics committee}

\section{REFERENCES}

1. Whiteman MK, Hillis SD, Jamieson DJ, Morrow B, Podgornik MN, Brett KM, et al. Inpatient hysterectomy surveillance in the United States, 20002004. Am J Obstet Gynecol. 2008;198:34.e1-7.

2. Johnson N, Barlow D, Lethaby A, Tavender E, Curr E, Garry R. Surgical approach to hysterectomy for benign gynecological disease. Cochrane Database Syst Rev. 2006;19(2):CD003677.

3. Hur HC, Guido RS, Mansuria SM, Hacker MR, Sanfilippo JS, Lee TT. Incidence and patient characteristics of vaginal cuff dehiscence after different modes of hysterectomies. J Minim Invasive Gynecol. 2007 May-Jun;14(3):311-7.

4. Hefermehl LJ, Largo RA, Hermanns T, Poyet C, Sulser T, Eberli D. Lateral temperature spread of monopolar, bipolar and ultrasonic instruments for robot-assisted laparoscopic surgery. BJU Int. 2014 Aug;114(2):245-52.

5. Meikle SF, Nugent EW, Orlear M. Complications and recovery from laparoscopy-assisted vaginal 
hysterectomy compared with abdominal and vaginal hysterectomy. Obstet Gynecol. 1997;89(2):304-11.

6. Campagnacci R, de Sanctis A, Baldarelli M, Rimini M, Lezoche G, Guerrieri M. Electrothermal bipolar vessel sealing device vs. ultrasonic coagulating shears in laparoscopic colectomies: a comparative study. Surg Endosc. 2007;21:1526-31.

7. Demirturk F, Aytan H, Caliskan AC. Comparison of the use of electrothermal bipolar vessel sealer with harmonic scalpel in total laparoscopic hysterectomy. J Obstet Gynecol Res. 2007;33:341-5.

8. Ashraf TA, Gamal M. Bipolar vessel sealer versus harmonic scalpel in laparoscopic supracervical hysterectomy. Gynecol Obstet. 2012;2:5.
9. Akira Tsunoda, Haruki Sada, Takuya Sugimoto, Nobuyasu Kano, Mariko Kawana, Tadanori Sasaki, et al. Randomized controlled trial of bipolar diathermy vs. ultrasonic scalpel for closed hemorrhoidectomy. World J Gastrointest Surg. 2011 Oct;3(10):147-52.

DOI: $10.5455 / 2320-1770 . i j r \operatorname{cog} 20141226$

Cite this article as: Bansal V, Bansal A, Bansal AK, Kumar A. Comparison between bipolar vessel sealer (LigaSure vessel sealer) and harmonic scalpel in total laparoscopic hysterectomy. Int J Reprod Contracept Obstet Gynecol 2014;3:1006-9. 